\title{
KNOWLEDGE AND ATTITUDE OF FEMALE UNDERGRADUATE DENTAL STUDENTS AND INTERNS TOWARDS RADIATION SAFETY AND PROTECTION
}

\author{
Ameera Alabdulwahid*
}

\begin{abstract}
Objective: The aim and objective of this study is to evaluate the level of knowledge and attitude about radiation hazards and safety practices among undergraduate female dental students and interns.

Materials and Methods: An electronic questionnaire was distributed among female dental students and interns at the College of Dentistry, King Saud University, using the online service SurveyMonkey.

Statistical Analysis: The collected data were analyzed using the IBM SPSS Statistical program version 26 (IBM Inc.NY, USA). Chi-square was used to test the association of the knowledge and attitude with the academic level.

Results: The surveys were completed by 156 dental students and interns, including 45 in the second year, 33 in the third year, 25 in the fourth year, 30 in the fifth year, and 23 dental interns.

Conclusion: The results obtained from this study indicate that radiological safety and protection measures shout be emphasized more throughout the undergraduate level as well as in continuous teaching courses for dental interns.
\end{abstract}

KEYWORDS: knowledge, attitude, dental radiographs, radiation safety, radiation protection

\section{INTRODUCTION}

Radiology has become a major field in diagnostic application in both medicine and dentistry. This field has grown enormously with the rapidly expanding range of imaging modalities. The use of radiology in dentistry has substantial benefits when utilized properly. It is the most widely used preclinical investigation tool. However, it is a doubleedged sword as exposure to ionizing radiation is considered a possible source of health hazards and biological effects. The effects on humans from ionizing radiation are the results of interactions at atomic level. Biological effects of radiation are broadly classified according to occurrence probability into Non-stochastic (deterministic) and

\footnotetext{
* Oral Medicine and Diagnostic Sciences, King Saud University, Riyadh, Saudi Arabia.
} 
stochastic effects. Deterministic effects are dose dependent, above which the biological damage appears in the body, and the severity of the response is proportional to the dose. The stochastic effect does not have a threshold dose that could lead to biological injury, so the probability of occurrence of the change, rather than its severity, is dose dependent ${ }^{1-3}$ All authorities support that radiation exposure of any tissue has the potential to induce malignant transformation and there is no specific radiation dose below which is considered safe 4,5. Therefore, compliance with the International Commission on Radiological Protection (ICRP) concept to as low as reasonably achievable As Low as Reasonably Achievable (ALARA) principles is essential in dentistry practice to ensure reducing patient exposure to ionizing radiation as minimally as possible ${ }^{6,7}$. However, the amount of radiation exposure from dental radiographs depends on many variables starting from the type of the receptor (films or digital receptors), going through exposure factors, collimation and protecting barriers. The undergraduate dental students and interns should have comprehensive knowledge of ionizing radiation's biological hazards and how to protect themselves and their patients ${ }^{8}$.

\section{MATERIALS AND METHODS}

An electronic questionnaire was distributed among dental students and interns at the College of Dentistry, King Saud University, using the online service SurveyMonkey. Second to fifth year undergraduate dental students and interns were included in the study. The collected data were analyzed using the IBM SPSS Statistical program version 26 (IBM Inc.NY, USA). Chi-square was used to test the association of the knowledge and attitude with the academic level. To compare the mean knowledge scores in the five academic groups, one-way analysis of variance (ANOVA) was used. A P-value equal to or less than 0.05 was considered to be statistically significant.

\section{RESULTS}

The surveys were completed by 156 dental students and interns, including 45 in the second year, 33 in the third year, 25 in the fourth year, 30 in the fifth year, and 23 dental interns as shown in figuer 1. Table 1 compares the knowledge of the participants towards radiation safety and protection. There were significant differences seen among the participants with regards to the knowledge regarding safety of digital radiography $(\mathrm{P}=0.038)$, holding the film/ sensor by patient during exposure $(\mathrm{P}=0.003)$, and wether radiation is contradicted during pregnency $(\mathrm{P}<0.001)$. On evaluating the attitude of the participants towards radiation safety and protection (Table 2), it was found that there was a significant difference seen in the awareness of the deterministic and stochastic effects of radiation $(\mathrm{P}=0.009)$. The average knowledge scores are presented in table 3 . The knowledge score differs between the five academic groups (one-way ANOVA: $\mathrm{F}_{4,151}=3.7$, $\mathrm{P}=0.007)$, where the score of fifth year dental students is significantly higher than the second year. 
TABLE (1) Knowledge of participants towards radiation safety and protection

\begin{tabular}{|c|c|c|c|c|c|c|c|c|}
\hline Question & Response & $\begin{array}{c}\text { 2nd year } \\
\mathrm{n}(\%)\end{array}$ & $\begin{array}{c}3 \text { rd year } \\
\text { n }(\%)\end{array}$ & $\begin{array}{c}\text { 4th year } \\
\mathrm{n}(\%)\end{array}$ & $\begin{array}{c}5 \text { th year } \\
\mathrm{n}(\%)\end{array}$ & $\begin{array}{c}\text { Interns } \\
\mathrm{n}(\%)\end{array}$ & $\begin{array}{l}\text { Total } \\
\mathrm{n}(\%)\end{array}$ & $\begin{array}{c}\mathrm{P} \\
\text { value }\end{array}$ \\
\hline \multirow{3}{*}{$\begin{array}{l}\text { Are x-rays used in } \\
\text { dentistry harmful? }\end{array}$} & yes & $14(31.1)$ & $20(60.6)$ & $9(36.0)$ & $13(43.3)$ & $7(30.4)$ & $63(40.4)$ & \multirow[t]{3}{*}{0.238} \\
\hline & no & $28(62.2)$ & $12(36.4)$ & $15(60)$ & $16(53.3)$ & $16(69.6)$ & $87(55.8)$ & \\
\hline & Idont_know & $3(6.7)$ & $1(3)$ & $1(4.0)$ & $1(3.3)$ & $0(0)$ & $6(3.8)$ & \\
\hline \multirow{3}{*}{$\begin{array}{l}\text { Can x-rays be } \\
\text { reflected from } \\
\text { constructed walls? }\end{array}$} & yes & $17(37.8)$ & $18(54.5)$ & $13(52.0)$ & $14(46.7)$ & $6(26.1)$ & $68(43.6)$ & \multirow[t]{3}{*}{0.255} \\
\hline & no & $19(42.2)$ & $12(36.4)$ & $9(36.0)$ & $10(33.3)$ & $15(65.2)$ & $65(41.7)$ & \\
\hline & Idont_know & $9(20)$ & $3(9.1)$ & $3(12)$ & $6(20)$ & $2(8.7)$ & $23(14.7)$ & \\
\hline \multirow{3}{*}{$\begin{array}{l}\text { Does digital } \\
\text { radiography } \\
\text { require less } \\
\text { exposure than } \\
\text { conventional? }\end{array}$} & yes & $29(64.4)$ & $32(97)$ & $21(84)$ & $24(80)$ & $18(78.3)$ & $124(79.5)$ & \multirow[t]{3}{*}{0.038} \\
\hline & no & $10(22.2)$ & $1(3)$ & $1(4)$ & $2(6.7)$ & $2(8.7)$ & $16(10.3)$ & \\
\hline & Idont_know & $6(13.3)$ & $0(0)$ & $3(12)$ & $4(13.3)$ & $3(13)$ & $16(10.3)$ & \\
\hline \multirow{3}{*}{$\begin{array}{l}\text { Do high-speed } \\
\text { films require } \\
\text { reduced exposure }\end{array}$} & yes & $28(62.2)$ & $21(63.6)$ & $16(64)$ & $22(73.3)$ & $17(73.9)$ & $104(66.7)$ & \multirow[t]{3}{*}{0.858} \\
\hline & no & $7(15.6)$ & $2(6.1)$ & $3(12)$ & $3(10)$ & $2(8.7)$ & $17(10.9)$ & \\
\hline & Idont_know & $10(22.2)$ & $10(30.3)$ & $6(24)$ & $5(16.7)$ & $4(17.4)$ & $35(22.4)$ & \\
\hline \multirow{3}{*}{$\begin{array}{l}\text { Do you prefer to } \\
\text { hold the films/ } \\
\text { sensors during } \\
\text { exposure? }\end{array}$} & yes & $3(6.7)$ & $1(3)$ & $4(16)$ & $1(3.3)$ & $4(17.4)$ & $13(8.3)$ & \multirow[t]{3}{*}{0.276} \\
\hline & no & $40(88.9)$ & $31(93.9)$ & $21(84)$ & $29(96.7)$ & $19(82.6)$ & $140(89.7)$ & \\
\hline & Idont_know & $2(4.4)$ & $1(3)$ & $0(0)$ & $0(0)$ & $0(0)$ & $3(1.9)$ & \\
\hline \multirow{3}{*}{$\begin{array}{l}\text { Do you ask the } \\
\text { patient to hold the } \\
\text { film/sensor with } \\
\text { their hand during } \\
\text { exposure? }\end{array}$} & yes & 7 (15.6) & $10(30.3)$ & $7(28)$ & $6(20)$ & $14(60.9)$ & $44(28.2)$ & \multirow[t]{3}{*}{0.003} \\
\hline & no & $35(77.8)$ & $18(54.5)$ & $18(72.0)$ & $22(73.3)$ & $9(39.1)$ & $102(65.4)$ & \\
\hline & Idont_know & $3(6.7)$ & $5(15.2)$ & $0(0)$ & $2(6.7)$ & $0(0)$ & $10(6.4)$ & \\
\hline \multirow{3}{*}{$\begin{array}{l}\text { Are dental } \\
\text { radiography } \\
\text { contraindicated in } \\
\text { pregnant patients? }\end{array}$} & yes & $27(60)$ & $13(39.4)$ & $7(28)$ & $0(0)$ & $6(26.1)$ & $53(34)$ & \multirow{3}{*}{$\begin{array}{c}< \\
0.001\end{array}$} \\
\hline & no & $15(33.3)$ & $18(54.5)$ & $17(68.0)$ & $29(96.7)$ & $17(73.9)$ & $96(61.5)$ & \\
\hline & Idont_know & $3(6.7)$ & $2(6.1)$ & $1(4)$ & $1(3.3)$ & $0(0)$ & $7(4.5)$ & \\
\hline
\end{tabular}


TABLE (2) Attitude of participants towards radiation safety and protection

\begin{tabular}{|c|c|c|c|c|c|c|c|c|}
\hline Question & Response & $\begin{array}{c}\text { 2nd year } \\
\mathrm{n}(\%)\end{array}$ & $\begin{array}{c}\text { 3rd year } \\
\mathrm{n}(\%)\end{array}$ & $\begin{array}{c}\text { 4th year } \\
\mathrm{n}(\%)\end{array}$ & $\begin{array}{c}5 \text { th year } \\
\mathrm{n}(\%)\end{array}$ & $\begin{array}{l}\text { Interns } \\
\mathrm{n}(\%)\end{array}$ & $\begin{array}{l}\text { Total } \\
\mathrm{n}(\%)\end{array}$ & $P$ value \\
\hline \multirow{2}{*}{$\begin{array}{l}\text { Are you aware } \\
\text { of NCRP/ICRP } \\
\text { recommendations? }\end{array}$} & yes & $14(31.1)$ & $9(27.3)$ & $12(48)$ & $9(30)$ & $13(56.5)$ & $57(36.5)$ & \multirow{2}{*}{0.102} \\
\hline & no & $31(68.9)$ & $24(72.7)$ & $13(52.0)$ & $21(70.0)$ & $10(43.5)$ & $99(63.5)$ & \\
\hline \multirow{2}{*}{$\begin{array}{l}\text { Are you aware of the } \\
\text { usefulness of collimators } \\
\text { and filters in dental } \\
\text { radiography? }\end{array}$} & yes & 39 (86.7) & $26(78.8)$ & $20(80)$ & $29(96.7)$ & $21(91.3)$ & $135(86.5)$ & \multirow{2}{*}{0.222} \\
\hline & no & $6(13.3)$ & $7(21.2)$ & $5(20)$ & $1(3.3)$ & $2(8.7)$ & $21(13.5)$ & \\
\hline \multirow{2}{*}{$\begin{array}{l}\text { Are you aware of } \\
\text { the deterministic and } \\
\text { stochastic effects of } \\
\text { radiation? }\end{array}$} & yes & $34(75.6)$ & $18(54.5)$ & $15(60)$ & $10(33.3)$ & $14(60.9)$ & $91(58.3)$ & \multirow{2}{*}{0.009} \\
\hline & no & $11(24.4)$ & $15(45.5)$ & $10(40)$ & $20(66.7)$ & $9(39.1)$ & $65(41.7)$ & \\
\hline \multirow{2}{*}{$\begin{array}{l}\text { Are you aware of the } \\
\text { ALARA principle }\end{array}$} & yes & $31(68.9)$ & $20(60.6)$ & $20(80)$ & $25(83.3)$ & $18(78.3)$ & $114(73.1)$ & \multirow{2}{*}{0.237} \\
\hline & no & $14(31.1)$ & $13(39.4)$ & $5(20)$ & $5(16.7)$ & $5(21.7)$ & $42(26.9)$ & \\
\hline \multirow{3}{*}{$\begin{array}{l}\text { Will you adhere to the } \\
\text { radiation protocol in the } \\
\text { future? }\end{array}$} & yes & $38(84.4)$ & $30(90.9)$ & $23(92)$ & $29(96.7)$ & $23(100)$ & 143 (91.7) & \multirow{3}{*}{0.357} \\
\hline & no & $3(6.7)$ & $2(6.1)$ & $0(0)$ & $0(0)$ & $0(0)$ & $5(3.2)$ & \\
\hline & Idont_know & $4(8.9)$ & $1(3.0)$ & $2(8)$ & $1(3.3)$ & $0(0)$ & $8(5.1)$ & \\
\hline \multirow{6}{*}{$\begin{array}{l}\text { Do you use lead aprons } \\
\text { on a regular basis? }\end{array}$} & always & $24(53.3)$ & $23(69.7)$ & $22(88)$ & $27(90)$ & 19 (82.6) & 115 (73.7) & \multirow{6}{*}{0.22} \\
\hline & often & $0(0)$ & $1(3)$ & $1(4)$ & $1(3.3)$ & $1(4.3)$ & $4(2.6)$ & \\
\hline & sometimes & $5(11.1)$ & $2(6.1)$ & $1(4)$ & $1(3.3)$ & $2(8.7)$ & $11(7.1)$ & \\
\hline & rarely & $1(2.2)$ & $2(6.1)$ & $0(0)$ & $1(3.3)$ & $0(0)$ & $4(2.6)$ & \\
\hline & never & $1(2.2)$ & $0(0)$ & $0(0)$ & $0(0)$ & $1(4.3)$ & $2(1.3)$ & \\
\hline & I dont know & $14(31.1)$ & $5(15.2)$ & $1(4)$ & $0(0)$ & $0(0)$ & $20(12.8)$ & \\
\hline
\end{tabular}

TABLE (3) Differences between the mean knowledge scores using one-way analysis of variance (ANOVA):

\begin{tabular}{|c|c|c|c|c|}
\hline academic year & $\mathrm{N}$ & Mean & $\begin{array}{c}\text { Std. } \\
\text { Deviation }\end{array}$ & \\
\hline 2nd_year & 45 & 56.5079 & 21.52695 & \multirow{2}{*}{ P value } \\
\hline 3rd_year & 33 & 68.3983 & 19.15218 & \multirow{2}{*}{0.007} \\
\cline { 1 - 4 } 4th_year & 25 & 65.7143 & 19.34295 & \\
\cline { 1 - 4 } 5th_year & 30 & 72.8571 & 21.66536 & \\
\cline { 1 - 3 } Intern & 23 & 57.7640 & 22.57877 & \\
\hline Total & 156 & 63.8278 & 21.61485 & \\
\hline
\end{tabular}

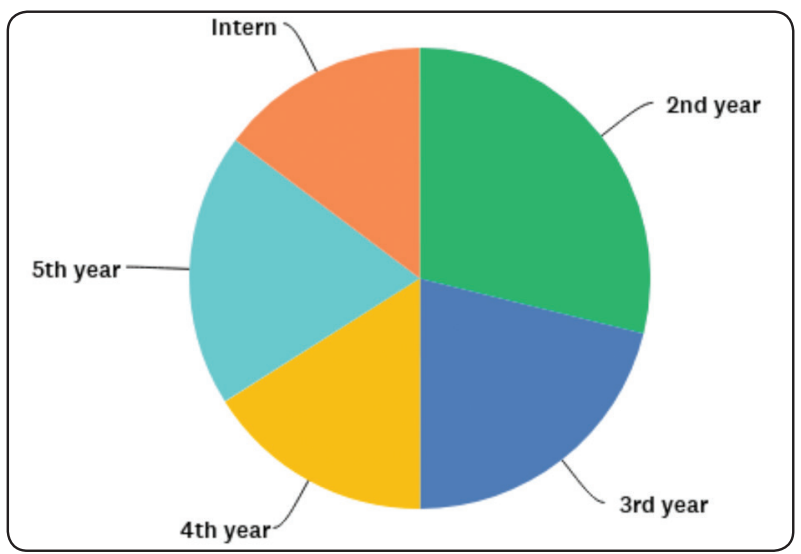

Fig. (1) Pie chart showing the distribution of participants 


\section{DISCUSSION}

Literature review showed that studies were deficient in evaluating the knowledge and attitude of dental undergraduate students and interns in Saudi Arabia. A study done by Arnout, et al ${ }^{9}$ showed that among undergraduate dental students, $87.5 \%$ considered x-rays to be harmful, while in this study, $87 \%$ believed that it is not. This is unexpected since students have been taught since day one of their first radiology course that $\mathrm{x}$-rays are potentially dangerous.

Furthermore, according to Arnout, et al., there was a question of whether X-ray can be reflected from the walls of the room, $69.7 \%$ of undergraduate students answered yes. A study done by Aldosimani ${ }^{10}$ showed that among undergraduate dental students, $53.6 \%$ considered $x$-rays to be harmful, and $48.3 \%$ thought that $\mathrm{x}$-rays could be reflected from the walls.

Since 1977, the International Commission on Radiological Protection (ICRP) started to implement the risk vs. benefit concept .All radiation exposure in medicine must be based on the ALARA principle (as low asreasonably achievable) ${ }^{4}$. In a study by Aravind, et al. ${ }^{11}$, dentists were asked about ALARA principle, and $84.3 \%$ answered that they know it. However, only $73.1 \%$ in this study mentioned that they are aware of it. When students and interns were asked about the importance of collimators and filtration in the dental X-ray machine, $86.5 \%$ answered yes white in Arnout, et al. study, only $30.3 \%$ of the undergraduate gave "yes" as an answer. Also, in their study, it has been shown that $68.0 \%$ of the participants claimed that they would adhere to radiation protection protocol in their future clinical practice. While in this study, $91.7 \%$ of the dental students and interns will adhere to radiation protection protocol in their future clinical practice.

Radiation exposure to pregnant women causes several biological effects on the fetus such as intrauterine death, developmental abnormalities, and mutagenic carcinogenic effects ${ }^{12}$. In pregnancy, it is better to avoid radiation exposure during the first trimester of pregnancy. If the radiological examination is unavoidable, it should be carried out during the second and third trimester with proper protection by utilizing lead apron, thyroid collar, etc. In the study by Swapna, et al. ${ }^{13}, 42 \%$ of the undergraduate dental students answered that it is contraindicated to make dental radiograph to pregnant, while in this study, $65.4 \%$ answered that it was not contraindicated. Similarly, Aldosimani ${ }^{10}$ found out that $54.9 \%$ of the undergraduate dental students answered that it is not contraindicated to make dental radiographs for pregnant.

\section{CONCLUSION}

The results obtained from this study indicate that radiological safety and protection measures shout be emphasized more throughout the undergraduate level as well as in continuous teaching courses for dental interns.

\section{REFRENCES}

1. White, S. C., \& Pharoah, M. J. White and Pharoah's Oral Radiology E-Book: Principles and Interpretation. (Elsevier Health Sciences, 2018).

2. Whaites, E. The biological effects and risks associated with X-rays. Essentials Dent. Radiogr. Radiol. 4th ed. London Churchill Livingstone Elsevier 29-33 (2007).

3. Council, N. R. Health risks from exposure to low levels of ionizing radiation: BEIR VII phase 2. (2006).

4. Valentin, J. International Commission on Radiological Protection. The 2007 recommendations of the international commission on radiological protection. Ann. ICRP, ICRP Publ. 103, 2-4 (2007).

5. Board, N. R. P. Guidance notes for dental practitioners on the safe use of X-ray equipment. (2001).

6. Horner, K. Radiation protection in dental radiology. Br. J. Radiol. 67, 1041-1049 (1994).

7. Syriopoulos, K., Velders, X.L., Van der Stelt, P.F., Van Ginkel, F.C. \& Tsiklakis, K. Mail survey of dental radiographic techniques and radiation doses in Greece. Dentomaxillofacial Radiol. 27, 321-328 (1998). 
8. Rabhat, M., Sudhakar, S., Kumar, B. P. \& Ramaraju. Knowledge, attitude and perception (KAP) of dental undergraduates and interns on radiographic protectionA questionnaire based cross-sectional study. J. Adv. Oral Res. 3, 45-50 (2012).

9. Arnout, E. Awareness of Biological Hazards and Radiation Protection Techniques of Dental Imaging- A Questionnaire Based Cross-Sectional Study among Saudi Dental Students. J. Dent. Heal. Oral Disord. Ther. 1, (2014).

10. Aldosimani, M. A. Awareness, Attitude And Behavior of Saudi Dental Students Towards Radiation Safety And
Protection. Int. J. Med. Dent. 24, (2020).

11. Aravind, B. S. et al. Attitude and awareness of general dental practitioners toward radiation hazards and safety. $\mathrm{J}$. Pharm. Bioallied Sci. 8, S53-S58 (2016).

12. Brent, R. L. The effect of embryonic and fetal exposure to $\mathrm{x}$-ray, microwaves, and ultrasound: counseling the pregnant and nonpregnant patient about these risks. Semin. Oncol. 16, 347-368 (1989).

13. Swapna, L. et al. Knowledge on Radiation Protection \& Practice among Dental Students. Br. J. Med. Med. Res. 19, (2017). 